\title{
Analytical Characterisation of Original Emulsion for Cosmetic Use
}

\author{
GABRIELA STANCIU ${ }^{1}$, ADINA-IOANA OANCEA $2,3 *$, ELENA OANCEA ${ }^{4}$, ELISABETA CHIRILA ${ }^{1}$ \\ ${ }^{1}$ Ovidius University of Constanta, Department of Chemistry and Chemical Engineering, 124 Mamaia Blvd., 900527, Constanta, \\ Romania \\ 2Politehnica University, Department of Inorganic Chemistry, Physical Chemistry and Electrochemistry, 1- 7 Polizu Str., 011061 \\ Bucharest, Romania \\ ${ }^{3}$ Careless Beauty Bucharest, 14 Viitorului Str., 020602, Bucharest, Romania \\ ${ }^{4}$ Careless Beauty Company, 9 Dobrogei Str., Topraisar, 907285 Constanta, Romania
}

\begin{abstract}
The aim of the paper is to characterize an original emulsion containing a mixture of plant macerates and essences. Next the wild and/or garden plants, namely Abies sp. (leaves), Crataegus monogyna (flowers), Hypericum perforatum (flowers), Lavandula angustifolia (flowers), Lavandula officinalis (flowers), Lilium sp. (flowers), Melissa officinalis (flowers), Mentha silvestris (leaves and flowers), Mentha piperita (leaves and flowers), Origanum vulgare (leaf blooms and flowers), Pinus silvestris (buds), Populus nigra (buds) and Thymus serpillum (flowers) have been processed to prepare the studied emulsion. Some of the emulsion ingredients as the essential oils of single plant and plant mixture, or the lily flowers macerate together with the final product have been analyzed. The measurements of physical and chemical properties (refractive index, density, $\mathrm{pH}$, oxidation-reduction potential, acidity index, peroxide index and iodine index) led to interesting results that could explain the curative effects on skin. The beneficial effects of new emulsion are due to the bioactive compounds that penetrate deep into the tissue and ensure regeneration. The obtained results confirm our previous findings concerning the opportunity of measurements of oxidation/reduction potentials for cosmetic mixtures regarding the antioxidant activity description.
\end{abstract}

Keywords: plant extracts, pH, oxidation-reduction potential, peroxide index, cosmetic emulsion

Since the oldes time, people craved for beautifying their body, face and hair. It has been discovered that the desire for beautification exists since the age of primitive humans. Historically, medicinal preparations are derived from plants, whether in the simple form of plant parts, or as crude extracts or mixtures, among others. Today a substantial number of drugs are developed from plants which are active against a number of diseases [1]. This might be due to the fact that plants are a particularly good source of compounds with antioxidant properties [2 - 5].

For example, total antioxidant activity of fruits and vegetables is thought to reflect concentrations of various antioxidant groups, the most commonly reported of which are phenolic compounds, ascorbic acid, $\alpha$-tocopherol, $\beta$ carotene and glutathione [6]. Crataegus monogyna, commonly known as hawthorn, revealed considerable concentrations of phenolics, flavonoids, ascorbic acid, tocopherols, $\beta$-carotene, saturated (hexadecanoic and tricosanoic) and polyunsaturated ((9Z,12Z)-octadeca-9,12dienoic and (9Z,12Z,15Z)-octadeca-9,12,15-trienoic) fatty acids [7].

In the last five years the cosmetic industry has reoriented its interest in plant extracts. The Natural Products Association (NPA) defines natural as ingredients that come from orare made from renewable resources found in nature [8]. Today the essential oils are seen as top ingredients for many kind of cosmetic products. This led to a new trend in the beauty industry called organic care. This is why today we hear so much about people looking for organic cosmetics or organic facials in beauty cliniques. Studies about characterisation of essential oils were already published [9-11]. The $\mathrm{pH}$ of the organic cosmetic products is an important parameter, whose optimum value should be within the range 4-5 to provide barrier protection and strengthening, to reduce the need for synthetic preservatives and to stabilize most of the active ingredients.
The study aims to make a physical and chemical characterization of (a) some plant extracts for cosmetics use (essential oils obtained from wild plants and plants carefully grown on cultivated areas as well as lily flowers macerate) and (b) one original cosmetic product obtained from the extracts mentioned above as an organic emulsion.

\section{Experimental part \\ Materials}

The plant species taking into the physical and chemical study were: wild mint (Mentha silvestris) and mint grown on cultivated lands (Mentha piperita), thyme (Thymus serpillum), oregano (Origanum vulgare), mellisa (Melissa officinalis), wild lavender (Lavandula angustifolia) and cultivated lavender (Lavandula officinalis), pine (Pinus silvestris), black poplar (Populus nigra), fir (Abies sp.), St. J ohn's wort (Hypericum perforatum), hawthorn (Crataegus monogyna) and lily (Lilium candidum).

Different plant materials, namely buds (pine and black poplar), leaves (fir), leaves and flow ers (mint, oregano) or only flowers (mellisa, thyme, lavender, St.j ohn's worth, hawthorn and lily) had been processed to prepare the studied original emulsion.

The plants were picked at full bloom and naturally dried on nets situated in an airy space. For the essential oil extraction of each plantspecies only dried plants have been used, butin order to obtain the essential oils from a mixture of plants both dried and fresh plants have been used. The method used for essential oil extraction was hydrodistillation with NeoClevenger device.

The lily flowers macerate was prepared from lily fresh flowers and lily polen by our own method [12].

In order to obtain the original cosmetic denoted as organic emulsion which is the object of this study, beside essential oils it has been used the lily flowers macerate. 
The lilly flowers oily macerate ( 92 - 95\%) and the mixture of twelve essential oils (5 - 8\%), are added in a brown glass container, shaked vigorously and stored properly.

\section{Measurements and equipments}

For the analytical characterisation of studied organic emulsion the following parameters have been determined:

-the density using Anton Paar SVM 3000 device;

-the refraction index - with Abbe digital refractometer;

- $\mathrm{pH}$ and oxidation/reduction potential (ORP) using a $\mathrm{pH}$ -meter pH 300 Oakton Instruments, with a combined electrode $\mathrm{Ag} / \mathrm{AgCl}$;

-acidity index - titration with $\mathrm{KOH} 0.1 \mathrm{~N}$ solution in the presence of phenolphthalein;

-peroxide index - titration with sodium thiosulfate 0.01

$\mathrm{N}$ solution in the presence of starch;

-iodine index - titration with sodium thiosulfate $0.1 \mathrm{~N}$ solution in the presence of starch.

\section{Clinical evaluation}

In order to evaluate the benefits in skin care of the studied organic emulsion, a clinical study was performed for 11 months on a person with acne caused by drugs administrated to treat a lung condition. The clinical study had the following phases:

Phase 1. The person used for eight months the prepared organic emulsion (external use only) as recommended by the esthetician.

Phase 2. The person used for the next three months the studied emulsion, (external use only) as recommended by the esthetician, in order to regenerate the scars remained on the epidermis.

\section{Results and discussions}

\section{Physico- chemical analyses}

Analyses were performed to justify the benefits in skin care of the plant extracts taken into study butalso to follow the variation of the $\mathrm{pH}$ and $\mathrm{ORP}$ in different plant extracts (esential oils obtained from wild plants and cultivated plants, esential oils obtained for a mixture of plant species or lily flowers macerate) contained by the prepared organic emulsion. Table 1 presents the measured density and refractive index of three esential oils: two of them have been obtained from single plant and one from a mixture of plant species (including oregano and thyme).

The measured parameters are not found in the regulations that specify the quality parameters of cosmetic ingredients, but we think that it can be a starting point for their description. It can be observed that the density varies between 0.8813 and $0.9180 \mathrm{~g} \cdot \mathrm{cm}^{-3}$ and the refraction index between 1.4765 and 1.4893. This values are similar with those reported in a study about essential oils for cosmetic use from South Africa [13]. Instead, the density of the essential oils obtained through hydrodistillation from nine medicinal herbs grown in Egipt, varied between 1.206 and $1.228 \mathrm{~g} \cdot \mathrm{cm}^{-3}$ [14].

The $\mathrm{pH}$ and the oxidation/reduction potential (ORP) have been measured for: (i) 9 individual essential oils extracted from single plant or plant mixture; (ii) the lily flowers macerate (table 2); and (iii) some samples of the prepared organic emulsion (table 2). One sample of this organic emulsion was measured after 3 days, 4 months, 8 months and 1 year to observe the $p H$ and ORP evolution in time.

A clinical study on 330 pacients has followed the $\mathrm{pH}$ values of the skin before and after $24 \mathrm{~h}$ from applying cosmetic products and the make-up removal process. Based on these observations, it can be estimated that the $\mathrm{pH}$ value of the skin surface is on average 4.7, i.e less than 5 , contrary to the general belief that the $\mathrm{pH}$ of the skin is between 5 and 6 [15].

The use of cosmetic products, particulary soaps and tap water, has a major influence on the grow th of skin pH which reaches over 6 . It has been shown that the skin with $\mathrm{pH}$ below 5 has a higher quality that the skin with $\mathrm{pH}$ over 5 by measuring parameters which consider biophysical barrier function externalities, moisturizing or by analysing the microflora concentrations of good for the skin [16].

We can mention that the beneficial microflora remains adherent on an acid skin ( $p H$ 4-4.5) but it totally disperses at $p H$ values of 8-9 [15].

The so-called mantle or skin barrier is composed of different chemical species of different origins, exogenous or endogenous. The exogenous substances are the products of the metabolism of bacteria.

Other substances in the barrier are produced in the human body and excreted at the skin surface: $\alpha$ hydroacids, lactic acid and butyric acid, present in sweating products, and acid lipids. Also, the cholesterol sulfate and free fatty acids released from sebaceous glands are transformed into other products and change the $\mathrm{pH}$ of the skin, this acidity being sometimes overestimated. Lactic acid and other acids diffuse back into the skin and they acidify the superficial layer of the corneum stratum. The

\begin{tabular}{|c|c|c|}
\hline Sample & Refractive index at $20^{\circ} \mathrm{C}$ & Density at $20^{\circ} \mathrm{C}, \mathbf{g}^{\cdot \mathbf{c m}^{-3}}$ \\
\hline Oregano (Origanum vulgare) & 1.4823 & 0.8813 \\
\hline Thyme (Thymus serpillum) & 1.4893 & 0.9180 \\
\hline Plant species mixture & 1.4765 & 0.9064 \\
\hline
\end{tabular}

Table 1

PHYSICAL PARAMETERS OF THREE ESENTIAL OILS FOR COSMETIC USE

\begin{tabular}{|c|c|c|}
\hline Specification & pH, units & $\begin{array}{l}\text { ORP, } \mathrm{mV} \text { versus } \mathrm{Ag} / \mathrm{AgCl} \\
\text { electrode }\end{array}$ \\
\hline Lavender grown on bio lands (Lavandula officinalis) & 4.05 & 163 \\
\hline \multirow[t]{2}{*}{ Thyme (Thymus serpillwm) } & 3.32 & 205 \\
\hline & 5.18 & 91 \\
\hline Mint grown on bio lands (Mentha piperita) & 4.02 & 164 \\
\hline Wild Mint (Mentha silvestris) & 3.98 & 163 \\
\hline Pine buds (Pinus silvestris) & 2.84 & 230 \\
\hline \multirow[t]{2}{*}{ Oregano (Origanum vulgare) } & 3.21 & 208 \\
\hline & 3.65 & 179 \\
\hline Black poplar (Popuius nigra) & 3.78 & 179 \\
\hline Dried plants mixture & 4.55 & 126 \\
\hline Mixture of thyme, oregano, wild lavander, pine buds and fir buds & 2.97 & 226 \\
\hline Lily macerate after 6 months & 5.38 & 81 \\
\hline
\end{tabular}

Table 2

PHYSICO CHEMICAL PARAMETERS OF THE ETHERIC OILS AND LILY MACERATE FOR COSMETIC USE 


\begin{tabular}{|c|c|c|}
\hline Specification & $\mathrm{pH}$, units & ORP, $\mathrm{mV}$ versus Ag/AgCl electrode \\
\hline Sample freshly analysed & 5.07 & 101 \\
\hline Sample analysed after 3 days & 4.43 & 136 \\
\hline Sample analysed after 3 weeks & 3.97 & 164 \\
\hline Sample analysed after 4 months & 3.96 & 168 \\
\hline Sample analysed after 8 months & 3.91 & 170 \\
\hline Sample analysed after 10 months & 3.86 & \\
\hline
\end{tabular}

Table 3

PHYSICO CHEMICAL PARAMETERS

EVOLUTION OF THE PREPARED ORGANIC EMULSION

\begin{tabular}{|l|c|c|}
\hline Product & $\mathrm{pH}$, units & $\begin{array}{c}\text { ORP, } \mathrm{mV} \text { versus } \\
\text { Ag/AgCl electrode }\end{array}$ \\
\hline Lily macerate & 5.38 & 81 \\
\hline Esential oils & $2.84-5.18$ & $90-230$ \\
\hline Prepared organic emulsion & $3.80-5.07$ & $101-170$ \\
\hline
\end{tabular}

Table 4

COMPARATION OF THE PHYSICO CHEMICAL VALUES BETWEEN PLANT EXTRACTS AND ORGANIC DERMATO COSMETICS FROM THIS STUDY filagrine compounds and other products of metabolism like urocanic acid and pirolidoncarboxilic acid, components of the natural moisturizing factor (FNH) as well as endogenous protons generated by the cellular carriers as a result of $\mathrm{Na}^{+} / \mathrm{H}^{+}$ion exchange may also be taken into consideration [16].

In the above cited paper, the author considers that the $\mathrm{pH}$ of the dermato-cosmetic products is a very important parameter, whose optimum value should be within 4-5, in order to maintain and strengthen the protective barrier, but in the same time, to reduce the need of synthetic additives as preservatives and to stabilize more active ingredients.

From our measurements it can be observed that both the ingredients and the final product (organic emulsion) have $\mathrm{pH}$ values below 5.3. The $\mathrm{pH}$ of organic emulsion decreases with the increase of storage time (table 3). Comparing the $\mathrm{pH}$ and ORP values obtained for the plant extracts taken into study with the ones reported for another plantextracts and original organic dermato cosmetics from the same source [17], we proved that the previous observation is true (table 4).

Researchers' opinion supports the practical observations noted over many years of external application of natural dermato cosmetics as a cure for various dermatological diseases, namely the profund moisturizing and regenerative effect on all types of skin.

The chemical parameters measured for the analytical characterization of the organic emulsion as final product and its ingredients were the acidity (IA), iodine index, and peroxide (IP) index. All determinations were performed in triplicate for one sample of lily macerate, two samples of organic emulsion, and another one for the sea buckthorn oil. The mean values are reported. Table 5 presents the obtained average values compared with reported values in literature. The higher IA values of organic elixir confirm the lower $\mathrm{pH}$ values, that assure the benefits in skin care.

The lower values of peroxide index indicate that the final organic emulsion contains higher amounts of antioxidants than other products, which ensure a high freshness. A significant contribution to the antioxidant activity could have the oxygenated monoterpenes from essential oils.

The iodine index value for final organic emulsion is higher than for lily flowers macerate, essential oils, African shea butter and argan oil, a fact that proves higher concentration in unsaturated compounds, with benefic effects on the skin cure; however, the final product does not ranced in time due to the high concentration of natural antioxidant compounds.

\begin{tabular}{|l|l|c|l|}
\hline \multicolumn{1}{|c|}{ Sample } & $\begin{array}{l}\text { IA, mg KOH/g } \\
\text { sample }\end{array}$ & $\begin{array}{r}\text { IP, meq } \\
\text { peroxide } / \mathrm{kg}\end{array}$ & $\begin{array}{l}\text { Iodine index, } \\
\text { g iodine/100g }\end{array}$ \\
\hline Lily flowers macerate & 10.27 & 8.0 & 0.17 \\
\hline Sample 1 of organic emulsion & 14.99 & 1.20 & 0.336 \\
\hline Sample 2 of organic emulsion & 21.20 & 1.01 & 0.47 \\
\hline Sea buckthorn oil & 7.40 & 7.86 & 0 \\
\hline Essential oils from South Africa & $0.33-33.7$ & $2.59-29.4$ & $0.06-0.149$ \\
\hline [13] & & & \\
\hline Shea Butter [18] & $4.10-6.01$ & $9.41-11.54$ & $0.048-0.05$ \\
\hline Argan oil[19] & 0.21 & 3.2 & 0.102 \\
\hline Dermato cosmetic creams [20] & $8.12-16.26$ & $9.7-19.54$ & $0.51-2.44$ \\
\hline
\end{tabular}

Table 5

AVERAGE VALUES OF THE ACIDITY INDEX (IA), PEROXIDE INDEX (IP) AND IODINE INDEX FOR ANALYSED NATURAL COSMETIC EXTRACTS AND THE PREPARED EMULSION, COMPARED WITH REPORTED VALUES IN LITERATURE 


\section{Clinical results}

The skin check-up performed by the esthetician led to the diagnosis of acne (pustular stage) with infection in the dermis tissue as a result of the accumulation of oxidized sebum.

The clinical study had the following phases:

Phase 1. For 8 months the person used our organic emulsion intended for healing acne (external use only) as recommended by the esthetician. After eliminating the infection due to the natural antibiotics from the plant extracts used in the composition of the cosmetic products, some visible scars remained on the epidermis.

Phase 2. For 3 months the person used the organic emulsion (external use only) as recommended by the esthetician, in order to regenerate the scars remained on the epidermis. At the end of phase 2, the epidermis was regenerated in a proportion of $70 \%$ ( fig. 1).

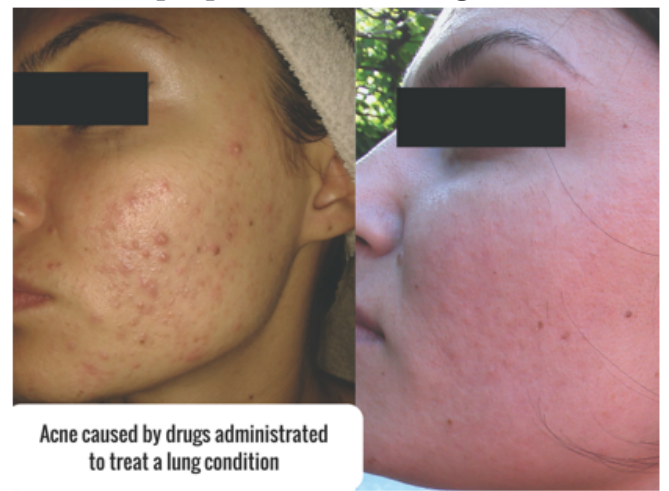

Fig.1. Skin condition before (a) and after (b) using the clinical study

The skin care benefits of the prepared organic emulsion is due to the bioactive compounds from the etheric oils extracted from wild plant species and cultivated plants, together with the lily flowers macerate. Some of the bioactive compounds have a better penetration of the epidermis and by reaching the dermis tissue (because of their small molecules), they improve the regeneration process of the cells.

\section{Conclusions}

The analytical characterisation of the plant extracts and the original organic emulsion prepared by us, led to the following conclusions:

The density and the refraction index were determined for essential oils extracted from both individual plant species and mixture of plants used in this organic emulsion for the first time.

The $\mathrm{pH}$ value of the prepared organic cosmetic product is weak acid.

The bioactive compounds present in the plant extracts and the prepared organic emulsion ensure optimum $\mathrm{pH}$ values and explains the long-term stability of these products, which do not contain synthetic chemicals.
The average values of the three chemical characteristics determined (acidity index, peroxide index and iodine index) are similar with the ones reported in the literature, for some ingredients in organic dermato-cosmetic products.

The obtained results confirm our previous findings concerning the opportunity of measurements of oxidation/ reduction potential for cosmetic mixtures regarding the antioxidant activity description.

\section{References}

1.HANEEFA M.K.P., HANAN S.K., SARASWATHI R., PRASAD G.M., CHANDINI N., Asian Pac. J. Trop. Med. 3, 2010, p.988.

2.STANCIU G., CHIRILA, E., DOBRINAS S., T.NEGREANU-PIRJOL, Rev. Chim (Bucharest), 61, no. 1, 2010, p.41.

3.MUKHERJ EE P.K., MAITY N., NEMA N.K., B.K SARKAR, Phytomedicine 19, 2011, p.64.

4.GONG H.Y., LIUD W.H., LV G.Y., ZHOU X., Rev. Bras. Farmacogn. 24, 2014, p.25.

5.LEE C-J, CHEN L-G, CHANG T-L, KE W-M, LO Y-F, WANG C-C, Food Chem. 124, 2011, p.833.

6.PENNINGTON J .A.T., FISHER R.A., J. Food Comp. Anal. 22, 2009, S23. 7.BARROS L., CARVALHO A.M., FERREIRA I.C.F.R., Phytochem. Anal. 22, 2011, p.181.

8.RUFFELL S. E., CARREIRO L. M., MULLER K. M., Cosmetics and Toiletries April 2016.

9.OZCAN M.M., OZCAN E., HERKEN E.N., J.Med. Food, 12(1), 2009, p.198.

10.TUREK C., STINTZING F.C., Comp. Rev. Food Sci. F, 12(1), 2013, p.40.

11.PELLEGRINI M., RICCI A., SERIO A., CHAVEZ-LOPEZC., MAZZARINO G., D'AMATO S., LO STERZO C., PAPARELLA A., Foods 7 (19) 2018, 14 pag., doi:10.3390/foods7020019.

12.0ANCEA E., OANCEA I.A., OANCEA T.N., OANCEA D., RO Patent application A00733/2015, BOPI 2, 2016, p.15.

13.VERMAAK I., KAMATOU G.P.P., KOMANE-MOFOKENG B., VILJOEN A.M., BECKETT K., S. Afr. J. Bot. 77, 2011, p.920.

14.TAREK N., HASSAN H. M., ABDELGHANI S.M.M., RADWAN I.A., HAMMOUD 0., EL-GENDY A. O., Beni- Suef Univ. J. Appl.Sci. 3, 2014, p.149.

15.LAMBERS H., PIESSENS S., BLOEM A., PRONK H., FINKEL P., Int. J. Cosmet. Sci. 28 (5), 2006, p.359.

16.WIECHERS J. W., Cosmetics and Toiletries Magazine, December $\mathbf{9}$, 2008; WIECHERS J. W, Skin delivery, What it is and why we need it, chapter 1 in: Science and Applications of Skin Delivery Systems, J.W. Wiechers (ed.), Allured Publishing, Illinois, USA, 2008, p.1-21

17.CHIRILA E., OANCEA E., OANCEA I.A., Ovidius University Annals of Chemistry 25(2), 2014, p. 75.

18. HONFO F.G., HELL K., AKISSOE N., LINNEMANN A., COULIBALY 0., J. Stored Prod. Postharvest Res., 3(3), 2012, p.24.

19.GHARBY S., HARHAR H., ROUDANI A., CHAFCHAOUNI I., CHARROUF Z., Int. J. Pharm. Sci. Invent. 2 (5), 2013, p.41.

20.POPESCU V., SOCEANU A., DOBRINAS S., Ovidius University Annals of Chemistry, 25 (2), 2014, p. 85.

$\overline{\text { Manuscript received: } 3.05 .2018}$ 